NUKHBATUL 'ULUM : Jurnal Bidang Kajian Islam

Vol. 4, No. 1 (2018) : Hal. 21-30

Website: https://journal.stiba.ac.id

ISSN : 2685-7537 (online) 2338-5251 (Printed)

\title{
MUHAMMADIYAH PARADIGMA GERAKAN SOSIAL KEAGAMAAN
}

\section{Muhammad Kasim Saguni}

Sekolah Tinggi Ilmu Islam dan Bahasa Arab (STIBA) Makassar,

Jl. Inspeksi PAM Manggala-Antang Makassar

E-mail: qasimsaguni@gmail.com

\begin{tabular}{|c|c|}
\hline Keywords : & $A B S T R A C T$ \\
\hline $\begin{array}{l}\text { muhammadiyah, social, } \\
\text { religion }\end{array}$ & $\begin{array}{l}\text { Mubammadiyah is one of the Islamic mass organizations establish in } \\
\text { the } 1912 \text { s and has operated in many aspects of life including religion, } \\
\text { social, education, healthcare, and politic. In addition, Mubammadiyah } \\
\text { has big impacts on determining the decisions and policies of the } \\
\text { Indonesian elites. This journal analyzes history of the establishment } \\
\text { and the development of Muhammmadiyah specifically on the efforts } \\
\text { conducted by Mubammadiyah, adopted religious paradigm, prominent } \\
\text { figures reactions to Mubammadiyah. }\end{array}$ \\
\hline
\end{tabular}


NUKHBATUL 'ULUM : Jurnal Bidang Kajian Islam

Vol. 4, No. 1 (2018) : Hal. 21-30

Website: https://journal.stiba.ac.id

ISSN : 2685-7537 (online) 2338-5251 (Printed)

\section{PENDAHULUAN}

Awal abad ke-20 silam, KH. Ahmad Dahlan berkomentar: "Islam tak mungkin lenyap dari seluruh dunia, tetapi tidak mustahil Islam hapus dari bumi Indonesia. Siapakah yang bertanggungjawab?" 1

Komentar tersebut merupakan wujud kegelisahan beliau tatkala menghadapi gencarnya upaya pemurtadan umat Islam Indonesia yang dilakukan penjajah Hindia Belanda. Ketika itu penjajah Belanda melakukan upaya pemurtadan dengan cara menciptakan kebodohan kaum Muslimin dalam kehidupan beragama.

Upaya pembodohan kaum Muslimin tersebut tidak lepas dari saran Prof. Snouck Hurgonye (Penasehat ahli pemerintah kolonial Belanda sering melakukan penyamaran sebagai ulama Timur Tengah untuk mengelabui umat Islam).

Snouck Hurgonye mengatakan bahwa untuk memurtadkan orang-orang Islam di Indonesia yang pada umumnya taat menjalankan perintah agamanya harus dilakukan secara halus, yaitu melalui pendekatan sosialisasi budaya Eropa / Belanda. Dengan cara pendekatan budaya, menurut Snouck, umat Islam Indonesia tidak bereaksi, dan bahkan natinya mereka akan murtad dan masuk Kristen dengan sendirinya. ${ }^{2}$

Selain itu, upaya pemurtadan terhadap umat Islam secara sistematis yang dilakukan penjajah Belanda adalah dengan cara semakin menyuburkan

${ }^{1}$ Firdaus AN, Dosa-Dosa yang Tak Boleh Terulang Lagi (Cet.II; Jakarta: Pedoman IImu Jaya, 1993), h. 35 paham / aliran menyimpang seperti bid'ah, takhayul, khurafat, dan segala bentuk kesyirikan. Tanpa disadari, sebagian besar umat Islam di Indonesia saat itu terjebak ke dalam penyakit agama tersebut.

Keadaan inilah yang menimbulkan gejolak kesedihan di hati KH. Ahmad Dahlan. Dengan berbekal kapabilitas ilmu keislaman yang ia pelajari dari ulama Ahlussunnah di Saudi Arabia selama lebih kurang 5 tahun, serta modal pengalamannya aktif berorganisasi di Syarikat Islam (dan menjadi salah satu pengurus pusatnya),akhirnya dengan mengharap ridha Allah SWT KH.Ahmad Dahlan mendirikan Muhammadiyah pada tanggal 18 November1912 M.

Tampilnya Muhammadiyah ke dalam dunia pergerakan nasional di Indonesia telah menjadi bahan kajian para pakar dari berbagai negara. Mengapa demikian?

Sebab Muhammadiyah berhasil eksis dalam percaturan kehidupan di berbagai bidang seperti agama, sosial, pendidikan, kesehatan, dan politik. Sejak didirikan pada tahun 1912 hingga kini, Muhammadiyah selalu memiliki pengaruh besar dalam menentukan arah dan kebijakan para elit masyarakat di Indonesia.

Pada zaman penjajahan Muhammadiyah banyak melahirkan tokoh-tokoh besar Islam tingkat nasional yang gigih berjuang melawan kolonialisme Belanda (yang beragama Nasrani) maupun Jepang (yang

${ }^{2}$ Hartono Ahmad Jaiz, Aliran dan Paham Sesat di Indonesia (Cet.l; Jakarta: Pustaka Al Kautsar, 2002), h. 294. 
berideologi Paganisme). Nama-nama seperti Jenderal Besar Sudirman (Pendiri sekaligus panglima pertama TNI), KH. Mas Mansyur (ulama yang melalui fatwanya berhasil menggerakkan perlawanan kaum Muslimin Jawa Timur berjihad melawan pendudukan NICA), Raden Mas Suryo (Gubernur Jawa Timur yang bersama KH. Mas Mansyur memimpin langsung perjuangan melawan NICA), serta masih banyak lagi yang lainnya.

Bahkan di beberapa daerah, tokohtokoh pimpinan militer setingkat Kodam yang mempelopori pemberontakan terhadap pemerintahan Soekarno (yang berniat mengembangkan ajaran komunisme di Indonesia), dengan mendirikan Darul Islam / Tentara Islam Indonesia (DI / TII) seperti RM. Sekarmaji Marijan Kartosoewiryo (Jawa Barat), dan Abdul Qahhar Muzakkar (Sulawesi Selatan) adalah kader-kader Muhammadiyah.

\section{Pemberontakan-pemberontakan}

tersebut dengan sangat terpaksa dilakukan para kader Muhammadiyah demi menyelamatkan eksistensi Islam dari bahaya komunisme yang mulai dianakemaskan pemerintahan Soekarno, seorang kader Muhammadiyah yang mengalami futur ${ }^{3}$ dan akidahnya telah menyimpang sehingga sangat membahayakan bagi dirinya sendiri maupun orang lain, karena saat itu posisinya sebagai orang nomor satu di negara ini.

\footnotetext{
${ }^{3}$ Yaitu suatu penyakit yang dapat menimpa sebagian orang-orang yang aktif mengurus Islam, bentuknya, yang paling minimal adalah rasa malas, menunda-nunda, atau berlambat-lambat dalam mengurus Islam dan dalam melakukan suatu amal-amal Islami lainnya. Sedangkan puncaknya adalah terputus dan berhenti sama sekali dalam aktifitas mengurus
}

Tidak hanya menelurkan tokoh-tokoh perjuangan kemerdekaan Indonesia saja, Muhammadiyah juga melahirkan tokoh-tokoh nasional yang berhasil menjadi elit politik masyarakat Indonesia di zaman kemerdekaan (terlepas apakah mereka masih istiqamah membela Islam atau justru malah memusuhi agama ini). Mereka yang pernah dibina oleh Muhammadiyah antara lain Ir. Soekarno (presiden pertama RI), Jenderal Soeharto (presiden kedua RI), H. Abdul Malik Karim Amrullah (Mantan Ketua Umum MUI Pusat yang dengan tegas mengeluarkan fatwa haramnya natalan bersama), serta masih banyak lagi nama-nama lainnya yang tidak dapat disebutkan satupersatu, termasuk Prof.Dr. Muhammad Amien Rais (Ketua Umum Majelis Permusyawaratan Rakyat RI periode 1999-2004).

Bahkan khusus Soeharto sendiri, dalam Muktamar Muhammadiyah ke43 di Banda Aceh beberapa tahun silam, mantan anggota Pembela Tanah Air (Peta) di zaman Jepang itu dengan bangga mengatakan bahwa ia adalah salah satu bibit kader Muhammadiyah. Pendidikan keagamaan yang pertama kali diperolehnya ketika Soeharto bersekolah di Schakel Muhammadiyah (setingkat SMP) di Yogyakarta.

Soeharto sering menyatakan dalam berbagai kesempatan:

Islam dan melakukan amal-amal Islami setelah sebelumnya rajin daan terus bergerak. (Lihat Sayyid Muhammad Nuh, Aafatun 'alath Thariq diterjemahkan oleh As'ad Yasin dengan judul Terapi Mentaal Aktifis Harakah (Cet.I; Solo: CV. Pustaka Mantiq, 1993), h. 15). 


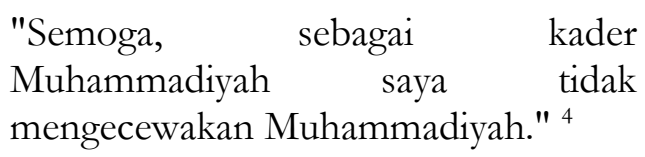

Perjalanan panjang Muhammadiyah dengan berbagai prestasi yang telah dihasilkannya sepanjang sejarah hidupnya telah membuktikan kepada masyarakat dunia bahwa Muhammadiyah adalah salah satu organisasi terbesar di muka bumi ini yang eksistensinya tidak dapat dipandang sebelah mata, termasuk oleh para musuh-musuh Islam.

Prestasi besar yang berhasil dilakukan Muhammadiyah menjadikan Peacock dalam bukunya Muslim Puritan memuji Muhammadiyah sebagai berikut:

"Mubammadiyah is the most powerful Islamic reformist movement ever exists in Southeast Asia, perbaps in the word."

Artinya:

"Muhammadiyah adalah pergerakan pembaharu Islam terkuat di Asia Tenggara, bahkan mungkin di dunia" 5

Muhammadiyah, dengan jumlah keanggotaannya yang sangat besar (terbesar di Indonesia, bahkan di Asia Tenggara), misi serta prestasinya dalam berbagai bidang kehidupan, serta pengaruhnya di negara ini dalam berbagai pengambilan kebijakan penting nasional, menunjukkan peningkatan pencapaian keberhasilan sebuah organisasi yang sangat mengesankan.

Berdasarkan gambaran seperti di atas itulah yang mendorong penulis untuk menyusun makalah sederhana ini.

${ }^{4}$ Adian Husaini, Soeharto 1998 (Cet.l; Jakarta: Gema Insani Press, 1997), h. 80.

${ }^{5}$ Alwi Shihab, Islam Inklusif Menuju Sikap

Terbuka dalam Beragama (Cet.V; Bandung: Mizan,1999), h. 303.
Makalah ini akan membahas permasalahan sebagai berikut:

1. Bagaimana sejarah berdiri dan perkembangan Muhammadiyah?

2. Apa saja amal usaha yang dijalankan Muhammadiyah?

3. Bagaimana pemikiran keagamaan yang dipahami Muhammadiyah?

4. Bagaimana tangapan para tokoh terkemuka tentang Muhammadiyah?

\section{PEMBAHASAN}

\section{Definisi Muhammadiyah}

Istilah 'Muhammadiyah' secara etimologis menurut pendirinya, $\mathrm{KH}$. Ahmad Dahlan adalah 'pengikut Muhammad'. Jadi secara terminologis arti 'Muhammadiyah' adalah 'orang yang menjadi pengikut dan penerus perjuangan Nabi Muhammad shallallabu 'alaibi wassalam secara konsekuen dan konsisten. ${ }^{6}$

Sementara itu, berdasarkan pandangan legalitas formal organisatoris, pengertian 'Muhammadiyah' adalah sebuah organisasi gerakan Islam, yang mempelopori dakwah Islam berupa amar makruf nahi munkar di Indonesia, yang berdiri berdasarkan Al Quran dan As Sunnah, dan berusaha mengikuti (ittiba') Rasulullah shallallahu 'alaibi wassalam untuk mengajak manusia mengamalkan Islam yang suci murni, 
jauh dari segala bid'ah, khurafat, syirik, dan takhayyul. ${ }^{7}$

\section{Sejarah Berdiri dan Perkembangan Muhammadiyah}

Sejarah kelahiran Muhammadiyah tidak bisa dipisahkan dari sejarah Syarikat Islam (SI), sebuah organisasi formal pertama di Indonesia. Pada tanggal 16 Oktober 1905 M seorang pengusaha Muslim dari Surakarta bernama $\mathrm{H}$. Samanhudi mendirikan organisasi Syarikat Dagang Islam (SDI). Tujuan didirikannya SDI adalah mengumpulkan seluruh potensi kaum Muslimin untuk mengusir penjajah Belanda dari bumi Nusantara.

Tiga tahun kemudian SDI dirubah namanya menjadi Syarikat Islam (SI) dengan alasan bahwa kata 'Islam' harus lebih ditonjolkan agar semakin banyak lagi umat Islam dari berbagai latar belakang profesi mau menyatukan barisan dan bergabung bersama SI untuk merebut kemerdekaan dari tangan penjajah.

Setelah dipimpin oleh HOS. Cokroaminoto, SI tampil sebagai organisasi besar yang berhasil menggalang ribuan anggota dan mendirikan cabang di berbagai kota di Jawa, Sumatera, Kalimantan, Sulawesi, dan Nusa Tenggara.

Eksistensi SI yang semakin merakyat membuat Pemerintah kolonial Belanda khawatir. Kekhawatiran tersebut wajar mengingat SI dapat membahayakan hegemoni penjajah Hindia Belanda

\footnotetext{
${ }^{7}$ Margono Puspo Suwarno, Gerakan Islam Muhammadiyah (Cet.III; Yogyakarta: Persatuan,1986), h. 3
}

yang telah 3 abad menguasi bumi Indonesia ini.

Setelah melihat perkembangan SI, dengan berbagai pertimbangan, setelah beberapa lama menolak permohonan izin berorganisasi bagi SI, namun Gubernur Jenderal Hindia Belanda pun akhirnya mengakui organisasi tersebut secara resmi dengan dikeluarkannya izin pada tanggal 10 September 1912. Alasan utamanya adalah agar SI mudah dikontrol.

Namun lain halnya bagi SI. Setelah izin bergorganisasi diperoleh dari Indenburg (sebutan untuk gubernur jenderal Hindia Belanda), sepak terjang HOS. Cokroaminoto dan kawan-kawannya semakin berani menyuarakan kemerdekaan. Kaum Muslimin pun tidak takut lagi terhadap pemerintah kolonial. Orang-orang Belanda waktu itu sangat menyesalkan sikap Indenburg yang berkenan memberikan izin bagi SI, sehingga ada ungkapan di kalangan orang-orang Belanda bahwa SI bukanlah singkatan 'Syarikat Islam' melainkan kepanjangannya adalah 'Salahnya Indenburg'. ${ }^{8}$

Mengingat garis perjuangan SI lebih memfokuskan pada bidang politik, maka KH. Ahmad Dahlan pun berfikir untuk mendirikan organisasi otonom di bawah SI yang membidangi pendidikan dan sosial. Rencana pendirian organisasi tersebut disetujui dan didukung penuh oleh HOS. Cokroaminoto, pimpinan SI saat itu.

Setelah melalui proses persiapan dan penjajagan, pada tanggal 18 November

8 Firdaus AN. Dosa-Dosa yang Tak Boleh Terulang Lagi, h. 61 
1912 M KH. Ahmad Dahkan mendeklarasikan berdirinya Muhammadiyah di Yogyakarta. Semula banyak orang heran dengan nama organisasi baru tersebut karena mirip nama wanita.

Memang dalam kaidah bahasa Arab akhiran -iah digolongkan ke dalam subyek muannas yang secara umum cenderung orang mengatakan dinisbatkan kepada wanita.

$\begin{array}{lrr}\text { Namun KH. Ahmad } & \text { Dahlan } \\ \text { menjelaskan } & \text { bahwa } & \text { arti } \\ \text { Muhammadiyah } & & \text { adalah } \\ \text { "Mubammadiyien" yang } & \text { bermakna } \\ \text { "pengikut Muhammad". } & \end{array}$

Ketika KH. Ahmad Dahlan mendirikan Muhammadiyah, beliau bukanlah orang terkenal dalam kepengurusan SI. Bahkan dalam urutan nama-nama pengurus SI saat itu, nama beliau di belakang HOS. Cokroaminoto. Di kalangan SI beliau hanya dikenal sebagai seorang guru agama Islam, sebuah profesi yang beliau geluti selama ini di Yogyakarta.

Namun setelah beberapa tahun kemudian, ketika Muhammadiyah tumbuh sebagai organisasi yang besar, dengan memiliki banyak anggota serta mengelola berbagai sekolah di banyak daerah, barulah nama beliau menjadi terkenal sehingga menyamai ketenaran HOS. Cokroaminoto.

Lima tahun setelah kelahiran Muhammadiyah, istri KH. Ahmad Dahlan (Nyai Hj. Ahmad Dahlan) mendirikan 'Aisyiyah pada tanggal 22 April 1917 M. sebagai wadah perjuangan pengembangan SDM Muslimah.
Pada awalnya (seperti penjelasan sebelumnya) Muhammadiyah merupakan organisasi otonom atau sayap moderat SI yang menitikberatkan pendidikan dan sosial, sementara SI sebagai organisasi induk memfokuskan diri pada bidang politik. Sehingga beberapa tahun lamanya Muhammadiyah dan SI saling bekerjasama memperjuangkan kemerdekaan umat Islam dari cengkeraman penjajah melalui bidang masing-masing. Bahkan banyak di antara pengurus memiliki keanggotaan rangkap serta memiliki status sebagai pengurus teras di dua organisasi tersebut.

Namun pada tahun 1927 (empat tahun setelah wafatnya KH. Ahmad Dahlan), ada ketidakcocokan strategi perjuangan antara SI dan Muhammadiyah. HOS. Cokroaminoto dan KH. Agus Salim memandang Muhammadiyah tidak sejalan lagi dengan SI karena organisasi yang didirikan KH. Ahmad Dahlan tersebut mau menerima subsidi pemerintah kolonial Belanda untuk membiayai operasional sekolahsekolahnya yang sangat banyak dan tersebar di seluruh Indonesia.

SI menganggap Muhammadiyah kooperatif terhadap penjajah padahal organisasi induknya non kooperatif. Maka pada Kongres SI di pekalongan tahun 1927 M tersebut terjadi penegakan disiplin organisasi. Para anggota / pengurus yang memiliki kartu keanggotaan rangkap disuruh memilih salah satu, apakah memegang kartu keanggotaan SI atau Muhammadiyah.

Keputusan kongres tersebut berlaku hingga proklamasi kemerdekaan dikumandangkan tanggal 17 Agustus 
1945 M di Jakarta. Setelah Indonesia merdeka, keputusan kongres tidak lagi dihiraukan anggota SI / Muhammadiyah. Mereka kembali bersatu dalam keanggotaan rangkap.

\section{Amal Usaha yang Dijalankan Muhammadiyah}

Sebagai sebuah lembaga Islam yang telah memiliki banyak anggota dan cabang di seluruh Indonesia, Muhammadiyah memiliki banyak amal usaha di berbagai bidang kehidupan. Saat ini di bidang pendidikan, Muhammadiyah telah memiliki dan mengelola lebih kurang 63 PTM (Perguruan Tinggi Muhammadiyah), yang terdiri atas 22 universitas, 11 institut, 23 sekolah tinggi, dan 7 akademi. ${ }^{9}$

Selain PTM, Muhammadiyah juga mengelola ribuan sekolah umum dari tingkat TK, SD sebanyak 1112 gedung sekolah, SMP/SLTP sebanyak 883 gedung sekolah, SMA, dan SMK di berbagai daerah. Khusus TK pada umumnya bernama TK Aisyiyah Bustanul Athfal (TK ABA) dikelola oleh Aisyiyah.

Organisasi yang berdiri tahun 1912 tersebut juga mengelola ribuan lembaga pendidikan agama berupa Muallimin / Muallimat, Madrasah Diniyyah (MD), Madrasah Ibtida'iyah (MI), Madrasah Tsanawiyah (MTs), Madrasah Aliyah (MA), serta pondok pesantren di seluruh Indonesia.

Pada bidang sosial lembaga ini mengelola panti asuhan dan panti

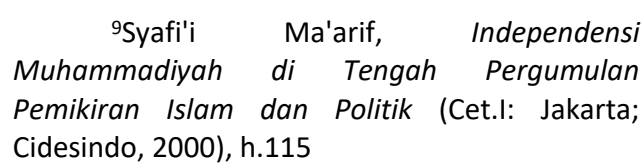

jompo yang jumlahnya 309 panti. Demikian pula di bidang kesehatan terdapat 311 amal usaha, yang terdiri atas rumah sakit (umumnya bernama Rumah Sakit Muhammadiyah) di berbagai kota, poliklinik, dan rumah bersalin (umumnya bernama Rumah Bersalin Siti Khadijah).

Pada bidang dakwah, lembaga ini telah menyebar ribuan muballighnya di seluruh daerah, temasuk di daerah terpencil sekalipun.

Di bidang informasi, Muhammadiyah masih menerbitkan majalah bulanan Suara Muhammadiyah dan mengelola situs mubammadiyah.or.id secara professional.

Di bidang ekonomi, Muhammadiyah memiliki sejumlah jenis usaha seperti Bank Perkreditan Rakyat (BPR), Bait Al-Tamwil (BTM), Badan Usaha Milik Muhammadiyah (BUMM), dan Koperasi Muhammadiyah, seluruhnya berjumlah 936 amal usaha. ${ }^{10}$

Pada lapangan politik, Muhammadiyah secara resmi tidak memiliki partai politik. Pada masa demokrasi terpimpin Muhammadivah (bersama beberapa ormas lainnya) berafiliasi membentuk Masyumi. Pada pemilu tahun 1971 bergabung dengan Partai Muslimin Indonesia. Selama orde baru lembaga ini menyalurkan aspirasi politiknya melalui Partai Persatuan Pembangunan (PPP). Setelah era reformasi, para pengurus Muhammadiyah atas nama personal mendirikan Partai amanat Nasional (PAN), partai pertama dalam sejarah

\footnotetext{
${ }^{10}$ Situs resmi Muhammadiyah
} 
yang menyalurkan aspirasi
Muhammadiyah dengan
berasaskan Islam.

\section{Pemikiran Keagamaan Yang Dipahami Muhammadiyah}

KH. Ahmad Dahlan mendirikan Muhammadiyah berusaha untuk mentransformasikan gerakan pemurnian Islam agar benar-benar sejalan dengan Al Quran dan As Sunnah, yang tidak disusupi virus-virus bid'ah, takhayul, khurafat, serta syirik yang melanda masyarakat Islam Indonesia saat itu. Beliau terpesona oleh keberhasilan gerakan pemurnian Islam yang dilakukan Syaikh Muhammad bin Abdul Wahhab dan para pengikutnya di Saudi Arabia.

Dari latar belakang tersebut dapat kita ketahui bahwa paham gerakan Muhammadiyah adalah Islam yang murni berdasarkan Al Quran dan As Sunnah sesuai pemahaman para Salafush shalih, yaitu ulama Ahlussunnah wal jamaah.

Namun demikian, belakangan ini di dalam tubuh Muhammadiyah terdapat krisis ulama. Maksudnya adalah, semakin kurang jumlah ulama Muhammadiyah yang berpengaruh besar serta memiliki latar belakangan ilmu syar'i yang dapat dipertanggungjawabkan, menjadikan garis pergerakan lembaga ini mengalami penyimpangan. Perlahan tapi pasti arah paham keagamaan Muhammadiyah mulai jauh dari prinsip yang dianut ulama Ahlussunnah wal

\footnotetext{
${ }^{11}$ Firdaus AN. Dosa-Dosa yang Tak Boleh Terulang Lagi.h. 42

${ }^{12}$ Hartono Ahmad Jaiz, Tasawuf,

Pluralisme, dan Pemurtadan, (Cet.l;Jakarta: Pustaka Al Kautsar,2001), h. 254.
}

Jamaah. Dalam tataran anggota di tingkat bawah, pada umumnya muballigh Muhammadiyah cenderung permisif dan turut serta dalam berbagai ritual yang oleh pendirinya sendiri (dan para ulama Salafush shalih lainnya) dikatakan bid'ah.

Selain itu, dalam tataran atas, para pimpinan Muhammadiyah cenderung pasif menghadapi manuver politik Islamphobia dalam pemberlakuan azas tunggal (mencoret Islam sebagai azas organisasi) pada tahun $1986 .{ }^{11}$

Tidak hanya itu, semakin banyaknya orang penting Muhammadiyah yang belajar Islam di Amerika Serikat (AS) turut memperburuk benteng aqidah Muhammadiyah. Sebagai contoh, Ketua Umum Muhammadiyah, A. Syafi'I Ma'arif secara terang-terangan menolak dimasukkannya (kembali) Piagam Jakarta ke dalam UUD $1945 .{ }^{12}$ Bahkan sebagai sesepuh Muhammadiyah (dan mantan ketua umumnya), M. Amien Rais pun enggan menjadikan PAN yang membawa aspirasi Muhammadiyah sebagai partai Islam.

\section{Tanggapan Para Tokoh Terkemuka Tentang Muhammadiyah}

Prof.Dr. Mitsui Nakamura (Pakar Sosial Politik Jepang) mengatakan:

"Muhammadiyah di Indonesia merupakan gerakan reformis Islam yang berhasil menyesuaikan diri dengan situasi masyarakat perkotaan." 13

\footnotetext{
${ }^{13}$ Din Syamsuddin (Ed.), Muhammadiyah Kini dan Esok (Cet.l;Jakarta: Pustaka Panjimas,1990), h. 139.
} 
Sementara itu KH. Firdaus AN (Mantan Wakil Presiden PSII) mengatakan:

"Sayang, Muhammadiyah pada akhirnya seperti NU, menghapus Islam sebagai asas dari bab II Anggaran Dasarnya. Suatu tragedi yang menyedihkan. Apakah itu tidak berdosa?" 14

Adian Husaini, MA. (Kandidat Doktor Politik Islam di ISTAC Malaysia) mengatakan:

"Syafi'i Ma'arif adalah Ketua Umum Muhammadiyah. Namun dikenal sebagai penentang dicantumkannya asas Islam bagi Muhammadiyah." 15

Dr.Marwah Daud Ibrahim (Anggota DPR-RI dari Fraksi Partai Golkar) mengatakan:

Muhammadiyah telah mengambil peran dalam meningkatkan keimanan umat Islam di Indonesia dengan jalan berdakwah pemurnian Islam agar terbebas dari takhayul, bid'ah, dan churafat (TBC). ${ }^{16}$

Dr. Howard M. Federspiel (Pakar Sosial Politik AS) mengatakan: "Sikap resmi Muhammadiyah adalah bahwa tak seorang pun yang mengaku Muslim bisa dipandang kafir. Gerakan Muhammadiyah mengambil sikap toleran dengan kelompok Muslim lainnya." ${ }^{17}$

\section{PENUTUP}

Dari uraian di atas dapat disimpulkan bahwa:

1. Muhammadiyah didirikan KH. Ahmad Dahlan pada tahun 1912 M sebagai wujud keprihatinan beliau terhadap penyimpangan agama kaum Muslimin serta upaya gencarnya upaya kristenisasi di Indonesia oleh penjajah Belanda. Muhammadiyah yang semula merupakan organisasi otonom di bawah Syarikat Islam (SI) semakin berkembang pesat sehingga mengalahkan SI dalam hal eksistensi hingga kini.

2. Sebagai organisasi yang sangat besar, Muhammadiyah kini memiliki banyak amal usaha dari berbagai bidang kehidupan, seperti pendidikan, dakwah, sosial, kesehatan, dan informasi

3. Semula Muhammadiyah didirikan untuk memurnikan ajaran Islam agar benar-benar sesuai dengan $\mathrm{Al}$ Quran dan As Sunnah sesuai pemahaman para Salafush shalih. Namun dalam perkembangannya kini terjadi beberapa penyimpangan berupa takhayul, bid'ah, khurafat, dan kesyirikan di sebagian anggota / pengurus Muhammadiyah.

4. Beberapa tokoh nasional dan luar negeri tertarik untuk mengkaji Muhammadiyah mengingat organisasi tersebut merupakan contoh lembaga yang berpengaruh di Asia Tenggara.

\footnotetext{
${ }^{14}$ Firdaus AN. Dosa-Dosa yang Tak Boleh Terulang Lagi h. 42.

${ }^{15}$ Adian Husaini, Penyesatan Opini Sebuah rekayasa Mengubah Citra.(Cet.l; Jakarta: Gema Insani Press, 2002), h.92
}

\author{
${ }^{16}$ Din Syamsuddin (Ed.), Muhammadiyah \\ Kini dan Esok. h. 148 \\ ${ }^{17}$ Din Syamsuddin (Ed.), Muhammadiyah \\ Kini dan Esok. h. 104
}




\section{DAFTAR PUSTAKA}

AN. Firdaus. Dosa-Dosa yang Tak Boleh Berulang lagi, Cet.II; Jakarta: Pedoman Ilmu Jaya, 1993.

Djamil, Fathurrahman. Metode Ijtihad majlis Tarjih Muhammadiyah. Cet.I; Jakarta: Logos Publishing House, 1995

Husaini, Adian. Soeharto 1998. Cet.I; Jakarta: Gema Insani Press, 1997.

Penyesatan Opini, Sebuah Rekayasa Mengubah Citra. Cet.I; Jakarta: Gema Insani Press, 2002.

Jaiz, Hartono Ahmad. Tasawuf, Pluralisme, dan Pemurtadan. Cet.I; Jakarta: Pustaka Al Kautsar, Maret 2001 . Aliran dan paham Sesat di Indonesia. Cet.I; Jakarta: Pustaka Al Kautsar, Pebruari 2002.

Ma'arif, M. Syafi'i.. Independensi Muhammadiyah di Tengah Pergumulan Pemikiran Islam dan Politik. Cet.I; Jakarta: Cidesindo,2000.

Majelis Tabligh Pimpinan Pusat Muhammadiyah. Islam dan dakwah, Pergumulan Antara Nilai dan Realitas. Cet.I; Yogyakarta, 1988.

Mansoer, KHM. Tanpa Tahun. 12 Tafsir Langkah Muhammadiyah. Yogyakarta: Majelis tabligh Pimpinan Pusat Muhammadiyah.
Nashir, Haedar. Ideologi Gerakan Muhammadiyah.

Cet.I;Yogyakarta: Suara Muhammadiyah, 2001.

Nuh, Sayyid Muhammad, Aafatun 'alath Thariq diterjemahkan oleh As'ad Yasin dengan judul Terapi Mental Aktifis Harakah. Cet.I; Solo: CV. Pustaka Mantiq, 1993.

Shihab, Alwi. Membendung Arus, Respons Gerakan Muhammadiyah terhadap Penetrasi Misi Kristen di Indonesia. Cet. I; Bandung: Mizan, 1998.

Islam Inklusif Menuju Sikap Terbuka dalam Beragama. Cet. V; Bandung: Mizan, 1999.

Syamsuddin, M. Din (Ed.). Muhammadiyah Kini \& Esok. Cet. I; Jakarta: Pustaka Panjimas, 1990.

Suwarno, Margono Puspo. Gerakan Islam Muhammadiyah. Cet.III; Yogyakarta: Persatuan, 1986.

www.muhammadivah.or.id (Situs resmi organisasi 